\title{
ASAS KELANGSUNGAN USAHA SEBAGAI LANDASAN FILOSOFIS PERLINDUNGAN HUKUM BAGI DEBITOR PAILIT SEHUBUNGAN TIDAK ADANYA INSOLVENCY TEST DALAM PENYELESAIAN SENGKETA KEPAILITAN
}

\author{
Serlika Aprita*
}

\begin{abstract}
In its development, the Bankruptcy Law in theory and practice did not progress significantly and it was until 1998 and replaced by a new one, which on October 18, 2004 legalized bankruptcy law and postponement of debt obligations have a wider scope, this is necessary because of the development and legal needs in the community while the provisions that have been applied is not sufficient as a legal means to solve the problem of accounts receivable in a fair, fast, open, and effective. One of them concerning the requirement to declare a bankrupt debtor as stipulated in the provisions of Article 2 paragraph 1 that there is no provision that requires the debtor to be insolvency, this is certainly contrary to the universal philosophy of the Bankruptcy Act that provides a way out for debtors and creditors when the debtor is in a state unable to pay its debts. The absence of this insolvency test shows that the Bankruptcy Act is dominant in protecting the interests of creditors. In order to have a clear philosophical foundation, the concept of business continuity principles should be included in the future Article of Bankruptcy Regulation so as to enable debtor and creditors to pursue debt settlement fairly, quickly, openly and effectively. The type of research in the writing of this journal is prescriptive normative legal research.
\end{abstract}

Kata Kunci: kepailitan, debitor, kreditor, insolvency test.

Pembangunan ekonomi di Indonesia pada awalnya dapat berjalan dengan baik, terlebih lagi dengan adanya program pembangunan ekonomi dari pemerintah secara bertahap dan berkesinambungan yang telah disusun pada masa pembangunan jangka panjang selama 25 tahun. Hal ini ditunjukkan dengan perkembangan ekonomi makro dan mikro yang meningkat pesat seiring dengan pertumbuhan unitunit usaha kecil atau besar di dalam dunia perdagangan dan ekonomi Indonesia. Fenomena ini mengakibatkan tingginya mobilitas sumber daya manusia dan sumber daya usaha, sehingga terjadi perputaran modal dan kekayaan yang membesar dari waktu ke waktu di dalam dunia perekonomian (Wisnu Ardytia, 2004: 1).

Pembangunan ekonomi di Indonesia sebelum tahun 1997, sebenarnya banyak para pihak yang memuji prestasi pembangunan ekonomi Indonesia sebagai salah satu High Performing Asian Economy Countries yang memiliki kinerja perekonomian yang sangat mengagumkan, bahkan ada yang menganggapnya sebagai miracle, akan tetapi hantaman krisis ekonomi yang berawal dari depresi rupiah pada Juli 1997, semua keajaiban itu menjadi sirna dan

*Program Doktor Ilmu Hukum Fakultas Hukum, UNSRI, koresponden penulis via email: http://5312lika@gmail.com 
terseok-seok dalam krisis ekonomi yang berkepanjangan sampai sekarang belum pulih kembali (Abdul Manan, 2009: 1).

Krisis ekonomi yang terjadi di Indonesia pada tahun 1997 menimbulkan pesimisme tentang jayanya ekonomi Indonesia di masa yang akan datang. Kondisi ini telah memporak-porandakan sendi-sendi perekonomian (Abdul R. Saliman, 2014: 118). Kesulitan yang sangat besar terhadap perekonomian nasional terutama terletak kepada kemampuan dunia usaha dalam mengembangkan usahnya (Zaeni Asyhadie \& Budi Sutrisno, 2012: 212). Dunia usaha merupakan dunia yang paling menderita dan merasakan dampak krisis yang tengah melanda, dimana pengusahapengusaha Indonesia tidak mampu membayar utang-utang mereka (dalam valuta asing) terhadap kreditor luar negeri bahkan ada yang berhenti membayar utang-utang mereka yang telah jatuh tempo (Mutiara Hikmah, 2007: 1 .

Satu jalan singkat yang ditempuh oleh kreditor untuk memperoleh pembayaran (meskipun hanya sebagian) pada saat debitor dalam keadaan berhenti membayar adalah melalui proses kepailitan (bankruptcy) (Sentosa Sembiring, 2006: 13). Penyelesaian masalah utang piutang berfungsi sebagai filter untuk menyaring atas dunia usaha dari perusahaan-perusahaan yang tidak efesien. Hal ini sebagaimana dijelaskan oleh Menteri KehakimanMuladi bahwa pada saat proses penyelesaian utang piutang diharapkan dapat terlaksana secara cepat, adil, terbuka, efesien, efektif dan profesional sehingga dunia usaha nasional dapat segera beroperasi secara normal dan pada gilirannya kegiatan ekonomi akan berjalan kembali (Muladi, dalam Rudhy A. Lontoh, Deny Kailimang, Benny Ponto(eds), 2001:181.

Hukum kepailitan di Indonesia dianggap belum dapat memberikan kepastian hukum. Hukum Kepailitan pada kenyataannya hanya merupakan suatu surat mati (Jerry Hoff, 2000: 2). Pada hakikatnya harus diakui pula bahwa permasalahanpermasalahan atau kendala prosedural yang timbul dalam penerapan Undang-Undang Kepailitan sudah ada sejak lama semenjak Tahun 1905 dimuat dan diatur dalam Peraturan Kepailitan yang sebelumnya berlaku, yaitu Faillisements Verordening S. 1905 Nomor 217 jo S. 1906 Nomor 348 (Kartini Muljadi, 2003: 1-10).

Pada perkembangannya, Hukum Kepailitan dalam teori dan praktek tidaklah mengalami kemajuan yang berarti dan hal ini dirasakan sampai pada tahun 1998 dan diganti dengan yang baru, dimana pada tanggal 18 Oktober 2004 disahkan UUK dan Penundaan Kewajiban Pembayaran Utang (selanjutnya disebut dengan UUK dan PKPU) mempunyai cakupan yang lebih luas, hal ini diperlukan karena adanya perkembangan dan kebutuhan hukum dalam masyarakat sedangkan ketentuan yang selama ini berlaku belum memadai sebagai sarana hukum untuk menyelesaikan masalah utang piutang secara adil, cepat, terbuka, dan efektif (Rahayu Hartini, 2009: 70).

Materi pokok perubahan dalam UUK dan PKPU satu di antaranya adalah menyangkut pengertian utang sebagaimana diatur dalam ketentuan Pasal 1 ayat 6 UUK dan PKPU dan mengenai syarat-syarat serta prosedur permohonan pailit dan permohonan penundaan kewajiban pembayaran utang termasuk di dalamnya pemberian kerangka waktu secara pasti bagi 
pengambilan putusan pernyataan pailit dan/atau Penundaan Kewajiban Pembayaran Utang (Syamsudin M. Sinaga, 2012: 31).

Luasnya pengertian utang berimplikasi pada dimensi Hukum Kepailitan secara umum, hal ini sebagaimana diatur dalam ketentuan Pasal 1 ayat 6 UUK dan PKPU yang mengartikan utang sebagai berikut:

Kewajiban yang dinyatakan atau dapat dinyatakan dalam jumlah uang baik dalam mata uang Indonesia maupun mata uang asing, baik secara langsung maupun yang akan timbul di kemudian hari atau kontinjen, yang timbul karena perjanjian atau undang-undang dan yang wajib dipenuhi oleh Debitor dan bila tidak dipenuhi memberi hak kepada Kreditor untuk mendapatkan pemenuhannya dari harta kekayaan debitor.

Maksud dari ditegaskannya dalam kepailitan yang dimaksud utang yang tidak dibayar lunas adalah untuk memastikan bahwa utang yang telah dibayar tetapi belum melunasi kewajban maka utang tersebut dapat dijadikan dasar untuk mengajukan kepailitan (Isis Ikhwansyah, Sonny Dewi Judiansyah, dan Rani Pustikasari, 2012: 26). Dalam Undang-Undang Kepailitan perluasan makna utang tidak diikuti dengan pembatasan nilai utang sebagai syarat untuk mengajukan permohonan pailit, artinya tagihan sekecil apapun baik yang timbul dari hubungan utang piutang maupun dari hubungan keperdataan lainnya yang dapat menimbulkan kewajiban pembayaran uang, dapat mengajukan permohonan pailit ke Pengadilan Niaga dan Hakim Pengadilan Niaga akan mengabulkan permohonan pailit jika telah terpenuhinya unsur-unsur sebagaimana diatur dalam ketentuan Pasal 2 ayat 1 UUK dan PKPU (Imran Nating, 2005: 26).

Syarat untuk menyatakan debitor pailit sebagaimana diatur dalam ketentuan Pasal 2 ayat 1 UUK dan PKPU tidak ada satu ketentuan yang mensyaratkan debitor harus dalam keadaan tidak mampu membayar (insolvency), hal ini tentunya bertentangan dengan filosofi universal dari Undang-Undang Kepailitan yaitu memberikan jalan keluar bagi debitor dan kreditor bilamana debitor sudah dalam keadaan tidak mampu membayar utang-utangnya. Ketiadaan insolvency test ini menunjukan bahwa Undang-Undang Kepailitan sangat dominan melindungi kepentingan kreditor (Hikmahanto Juwana, 2004: 17. Praktek penjatuhan pailit dalam Undang-Undang Kepailitan banyak menimbulkan problematik dan debat yuridis salah satu penyebabnya adalah karena banyakanya pengaturan yang tidak jelas sehingga memberikan peluang untuk melakukan beragam penafsiran yang berakibat ketidakpastian hukum bagi pencari keadilan (Surya Perdamaian, 2001: 5).

Insolvensi merupakan sebuah tahapan yang sangat penting dalam kepailitan karena pada tahapan ini nasib debitor ditentukan apakah harta debitor akan habis dibagi untuk menutup utangnya atau utang yang akan timbul di masa yang akan datang ketika diterimanya suatu rencana perdamaian atau restrukturisasi utang. Pengaturan insolvensi pada dasarnya telah diatur dalam Peraturan Perundang-Undangan pada zaman kolonial Belanda hingga pada Peraturan Perundang-Undangan hukum nasional. Tujuan Hukum 
Kepailitan sebagai suatu sita umum dalam Faillisements Verordening tidak diikuti dengan pengaturan secara tegas mengarah kepada tujuan itu. Ketidaktegasan pengaturan dalam Faillisements Verordening mempengaruhi penegakannya. Misalnya syarat pernyataan pailit dalam Faillisements Verordening adalah terbukti "secara sumir" adanya keadaan-keadaan yang menunjukan debitor "telah berhenti membayar". Namun demikian, dalam ketentuan Faillisements Verordening tidak terdapat penjelasan resmi tentang pengertian "secara sumir" dan "telah berhenti membayar". Pengertian "dalam keadaan berhenti membayar" tidak diatur secara rinci dalam Faillisements Verordening, hal ini menimbulkan dua penafsiran yaitu debitor tidak mampu lagi membayar atau debitor tidak mau (meskipun mampu) membayar (Wirjolukito, 1997: 3-7).

Krisis moneter yang terjadi di Indonesia pada pertengahan 1997 mendorong lahirnya Peraturan Pemerintah Pengganti UndangUndang Nomor 1 Tahun 1998 tentang Perubahan atas UndangUndang tentang Kepailitan. Peraturan Pemerintah Pengganti Undang-Undang Nomor 1 Tahun 1998 tentang Perubahan atas Undang-Undang tentang Kepailitan disetujui oleh Dewan Perwakilan Rakyat dan disahkan menjadi Undang-Undang Nomor 4 Tahun 1998 pada tanggal 9 Sepetember 1998. Tujuan pengesahan kebijakan ini hanya untuk melindungi kepentingan kreditor asing, hal ini dengan jelas dapat dilihat dalam Pasal 1 ayat 1 Undang-Undang Nomor 4 Tahun 1998 yang tidak mempertimbangkan apakah debitor dalam keadaan solven atau insolven untuk dinyatakan pailit. Dalam perjalananya Undang-Undang Nomor 4 Tahun 1998 tidak memberikan perlindungan terhadap debitor solven.

Penggantian Fallisements Verordening dengan Undang-Undang Nomor 4 Tahun 1998 ternyata belum juga memenuhi perkembangan dan kebutuhan hukum masyarakat. Selanjutnya UUK dan PKPU menggantikan Undang-Undang Kepailitan sebelumnya. Sama halnya dengan praktik penegakan Undang-Undang Nomor 4 Tahun 1998 ketiadaan perlindungan hukum terhadap debitor solven juga ditemukan kembali dalam UUK dan PKPU. Pengadilan Niaga Jakarta Pusat menyatakan pailit suatu perusahaan yang solven yaitu PT. DI, hal ini merupakan salah satu akibat dari ketiadaan filosofi dalam Undang-Undang Kepailitan sehingga hakim hanya memutuskan debitor pailit hanya mendasarkan diri pada syarat adanya dua utang dan salah satunya telah jatuh tempo.

Kondisi demikian menimbulkan ketidakadilan jika atas jumlah tagihan yang kecil lalu sebuah perusahaan besar dengan nilai aset lebih dari sepuluh kali lipat nilai tagihan para kreditornya harus dinyatakan pailit dengan konsekuensi bahwa semua pengurusan atas harta kekayaan perusahaan debitor tersebut beralih kepada kurator dan kelangsungan perusahaannya akan ditentukan oleh penyelesaian proses pailit artinya jika terjadi perdamaian antara debitor dengan 
para kreditor dan perdamaian itu disahkan maka masa depan perusahaan akan kembali seperti semula, namun jika perdamaian ditolak dan dilanjutkan ke tahap eksekusi maka sudah dapat dipastikan perusahaan debitor berada di ujung tanduk yang menimbulkan konsekuensi hukum debitor dinyatakan pailit diikuti dengan penyitaan umum yang dilakukan oleh yang berwenang yang diikuti dengan pembagian sama rata hal ini sebagaimana diperkuat oleh pendapat Man S. Sastrawidjaja (Man S. Sastrawidjaja, 2006: 81).

Secara umum dalam Hukum Kepailitan debitor baru dapat dinyatakan pailit apabila debitor tersebut berada dalam keadaan tidak mampu membayar (solven), hal ini sebagaimana konsep pengertian umum pailit menunjuk kepada kondisi debitor yang tidak mampu membayar utangnya lagi (insolvensi) (Nina Nurani, 2009: 215). Berdasarkan ketentuan Penjelasan Pasal 57 ayat 1 UUK dan PKPU menyatakan bahwa insolvensi adalah keadaan tidak mampu membayar. Untuk hal ini kreditor diberikan waktu dua bulan untuk menggunakan hak khususnya terhadap keadaan insolventie tersebut (Bagus Irawan, 2007: 50), dikarenakan pada tahap ini nasib debitor pailit ditentukan apakah harta debitor akan habis dibagi sampai menutupi utangnya atau diterimanya perdamaian atau restrukturisasi utang untuk mempailitkan debitor UUK dan PKPU. Jadi hukum kepailitan hanya dipergunakan apabila debitor tidak mampu (insolven) untuk membayar utang-utangnya kepada semua kreditornya.

Berdasarkan ketentuan Pasal 2 ayat 1 UUK dan PKPU menunjukan bahwa tidak adanya ketentuan yang mensyaratkan debitor dalam keadaan insolvensi. Hal ini tentu melindungi kepentingan kreditor dengan tidak diterapkannya insolvency test mengakibatkan perusahaan Indonesia bangkrut secara hukum padahal kondisi ekonomi Indonesia saat ini apabila syarat insolvensi diterapkan maka akan membuat debitor sulit untuk dinyatakan pailit (Siti Soemarti Hartono, 1981: 53). Seharusnya konsep insolvency test dimasukkan dalam UUK dan PKPU dalam rangka pemberian perlindungan hukum kepada debitor, selain untuk mengetahui apakah ketidakmampuan membayar debitor disebabkan karena perusahaan bangkrut atau karena alasan tertentu. Namun sayangnya kondisi solven debitor Indonesia ini tidak diperhatikan oleh para penyusun Undang-Undang Kepailitan, faktor emosional untuk menghukum pihak bersalah mendominasi penyusun undang-undang tersebut (Sunarmi, 2005: 58-59).

Berbagai fakta hukum menunjukan tidak rasionalnya syaratsyarat pailit sebagaimana diatur dalam ketentuan Pasal 2 ayat 1 UUK dan PKPU dalam Undang-Undang Kepailitan kita, berikut ini beberapa kasus hukum yang menunjukan betapa tidak rasionalnya syarat-syarat pailit yang tidak memberikan manfaat dan perlindungan hukum bagi kreditor dan debitor secara seimbang yaitu kasus pailitnya perusahaan-perusahaan nasional seperti PT. Telkom dan PT. Prudential Life di Pengadilan Niaga menunjukan bahwa perusahaan yang dikenai putusan pailit tersebut dinilai masih layak untuk melanjutkan kelangsungan usahanya.

Pailitnya perusahaan-perusahaan yang masih memiliki prosepektif untuk tetap dilanjutkan disebabkan ketiadaan 
persyaratan mengenai insolvency test untuk menyatakan debitor pailit. Selain itu pula, kasus pailitnya perusahaan nasional yang masih prospektif seperti PT. Prudential Life Assurance dan PT. Telkom menunjukan bahwa Undang-Undang Kepailitan di Indonesia telah menghilangkan klausula "debitor yang tidak mampu membayar", dimana klausula ini memiliki dua makna yaitu debitor yang benarbenar tidak memiliki kemampuan untuk membayar atau debitor yang tidak mau membayar, padahal memiliki kemampuan untuk membayar utang-utangnya.

Pengaturan asas kelangsungan usaha dalam Hukum Kepailitan juga mempunyai peranan penting dalam memberikan perlindungan hukum bagi debitor yang memiliki kemampuan untuk melakukan restrukturisasi perusahaan sebagai upaya perwujudan asas keadilan bagi semua pihak (Adrian Sutendi, 2009: 9). Restrukturisasi merupakan pemberian kesempatan kepada debitor yang tidak memiliki kemampuan untuk membayar utang tetapi perusahaan debitor tersebut memiliki potensi besar untuk dapat melangsungkan kegiatan usahanya sehingga debitor mampu melakukan pelunasan utang terhadap kreditor-kreditornya. Sebelum dilakukan proses restrukturisasi terlebih dahulu diawali dengan studi kelayakan yang bertujuan untuk menentukan apakah utang debitor layak atau tidak untuk dilakukan restrukturisasi (Yuanita Harahap).

Konsep asas kelangsungan sebagai landasan filosofis perlindungan hukum debitor pailit sehubungan dengan tidak adanya insolvency test dalam penyelesaian sengketa kepailitan bagi debitor yang belum terwujud ini harus diperhatikan dikarenakan berkaitan dengan nilai keadilan dan nilai kepastian hukum bagi debitor (Rr. Dijan Widijowati, 2012: 226). Konsep perlindungan hukum yang diberikan Pemerintah Republik Indonesia dalam memberikan suatu jaminan kepada semua pihak dalam hal ini kaitannya dengan debitor untuk dapat melaksanakan hak dan dan kepentingan hukum yang dimilikinya dalam kapasitasnya sebagai subjek hukum belum maksimal (Junita Eko Setiyowati, 2003: 13). Yang dimaksud hak di sini adalah kekuasaan untuk melakukan sesuatu karena telah ditentukan oleh Undang-Undang (Sudarsono, 2002: 154). Jaminan perlindungan hukum yang diberikan oleh negara ini berkesesuaian dengan ketentuan Pasal 1 ayat 3 UUD NRI Tahun 1945 menyatakan bahwa "Indonesia adalah negara hukum". Jaminan yang dimaksud adalah perlindungan hukum bagi debitor melalui upaya menciptakan peraturan hukum mengenai pengaturan landasan filosofis pengaturan asas kelangsungan usaha dalam UUK dan PKPU sebagai landasan filosofis perlindungan hukum debitor solven dalam putusan pernyataan pailit sehubungan tidak adanya insolvency test (Martiman Prodjohamidjojo, 2002: 86).

Kondisi ini menunjukan bahwa perlindungan hukum bagi debitor dalam hal ini menunjukan bahwa belum tercapainya asas keseimbangan bagi debitor dan kreditor sebagaimana dianut oleh UUK dan PKPU, padahal konsep perlindungan hukum seimbang bagi debitor dan kreditor dalam Undang-Undang Kepailitan sejalan dengan konsep dari perlindungan kepentingan yang seimbang dengan dasar Negara RI yaitu Pancasila. Berdasarkan konsep perlindungan hukum berlandaskan Pancasila 
dijelaskan bahwa kepentingan semua pihak atau masyarakat harus tetap diutamakan, tanpa mengutamakan kepentingan individu atau pribadi. Atas dasar penjelasan tersebut, menunjukan bahwa konsep perlindungan hukum berlandaskan Pancasila di dalamnya terkandung makna hak asasi manusia. Hak asasi manusia yang dimaksud adalah mengutamakan kepentingan dan kewajiban semua pihak atau masyarakat. Berdasarkan sila "Kemanusiaan yang adil dan beradab" harus dikembangkan sikap tidak semena-mena terhadap orang lain.

Konsep perlindungan kepentingan seimbang yang diatur dalam Pancasila ini menunjukan adanya pengakuan terhadap hak asasi manusia. Dalam ketentuan Pasal 1 ayat 1 Undang-Undang Nomor 39 Tahun 1999 tentang Hak Asasi Manusia menyatakan bahwa:

"Hak asasi manusia adalah seperangkat hak yang melekat pada hakikat dan keberadaan manusia sebagai mahluk tuhan Yang Maha Esa dan merupakan anugerah-Nya yang wajib dihormati, dijunjung tinggi dan dilindungi oleh negara, hukum, pemerintah, dan setiap orang demi kehormatan serta perlindungan harkat dan martabat manusia”.

Berdasarkan ketentuan pasal di atas menunjukan bahwa baik debitor maupun kreditor mempunyai hak asasi manusia dimana hak ini melekat pada hakikat dan keberadaan manusia sebagai anugerah Tuhan Yang Maha Esa harus dilindungi oleh negara, pemerintah, dan hukum. Atas dasar ini maka Undang-Undang Kepailitan harus memberikan perlindungan seimbang bagi debitor dan kreditor sebagai perwujudan pemenuhan perlindungan hak asasi manusia (Daniel F. Aling, 2009: 4). Hal ini dikarenakan suatu Undang-Undang Kepailitan yang baik haruslah dilandaskan pada asas perlindungan yang seimbang bagi semua pihak yang terkait dan berkepentingan dengan kepailitan. Sehubungan dengan itu, Undang-Undang Kepailitan yang baik seyogyanya tidak hanya memberikan perlindungan bagi kreditor tetapi juga bagi debitor.

Perlindungan hukum yang tidak seimbang bagi debitor berkaitan erat pula dengan hubungan antara HAM dan demokrasi merupakan konsepsi kemanusiaan dan relasi sosial yang dilahirkan dari sejarah peradaban manusia di seluruh penjuru dunia. HAM dan demokrasi dapat juga dimaknai sebagai hasil perjuangan manusia untuk mempertahankan dan mencapai harkat kemanusiaannya sebab hingga saat ini hanya konsepsi HAM dan demokrasilah yang terbukti paling mengakui dan menjamin harkat kemanusiaan hal ini sebagaimana dijelaskan oleh Jimly Asshiddiqie (Jimly Ashiddiqie, 2014: 21).

Asas kelangsungan usaha ini memberikan kesempatan bagi debitor untuk melakukan restrukturisasi terhadap perusahaannya yang bertujuan untuk mencegah terjadinya kesewenang-wenangan pihak penagih yang mengusahakan pembayaran atas tagihan masingmasing terhadap debitor, dengan tidak memperdulikan kreditor lainnya dengan jalan menyatakan debitor solven pailit (Victorianus 
M.H. Randa Puang, 2011: 10). Asas kelangsungan usaha yang merupakan landasan filosofis perlindungan hukum bagi debitor sehubungan dengan tidak adanya insolvency test dalam kaitannya pula dengan memberikan perlindungan hukum yang seimbang bagi debitor dalam penerapan perkara pailit masih sering terabaikan mengingat UUK dan PKPU menitikberatkan asas tersebut pada proses pemberesan harta debitor setelah pernyataan pailit diucapkan, kondisi tersebut menimbulkan keniscayaan bahwa Hakim dalam perkara Niaga tidak pernah mempertimbangan asas kelangsungan usaha dalam pertimbangan untuk menjatuhkan putusan pailit ketika syarat sebagaimana diatur dalam Pasal 2 ayat 1 UUK dan PKPU telah terpenuhi, padahal nyata-nyata menempatkan sebuah perusaahaan yang memiliki prospek bisnis dan solvabilitas yang baik dalam keadaan pailit akan banyak menimbulkan kerugian bagi perusahaan dan masyarakat pada umumnya. Selain itu pula, padahal dalam teori Hukum Kepailitan Modern, teori kepailitan sebenarnya dimulai dengan mengakui sistem kepailitan yang diperlukan untuk mencari pemecahan masalah berkaitan dengan pengembalian utang dari suatu perusahaan yang mengalami kesulitan likuiditas (insolvency) untuk membayar utang-utangnya (Andriani Nurdin, 125).

Kajian ini lebih fokus pada bagaimana pengaturan asas kelangsungan usaha dalam Undang-Undang Nomor 37 Tahun 2004 tentang Kepailitan dan Penundaan Kewajiban Pembayaran Utang (PKPU) sebagai landasan filosofis perlindungan hukum debitor pada putusan pernyataan pailit sehubungan tidak adanya insolvency test dalam penyelesaian sengketa kepailitan. Selain itu pembahasan tentang bentuk dan mekanisme perlindungan hukum terhadap kelangsungan usaha debitor yang masih prospektif sesudah putusan pailit dan sesudah berakhirnya kepailitan sehubungan tidak adanya insolvency test dalam penyelesaian sengketa kepailitan.

\section{Nilai-Nilai yang Mendasari Asas Kelangsungan Usaha}

Pada penerapannya hukum dituntut untuk memenuhi berbagai karya yang oleh Gustav Radbruch yaitu keadilan, kemanfaatan dan kepastian hukum disebut sebagai nilai-nilai dasar hukum. Sekalipun keadilan, kemanfaatan, dan kepastian hukum merupakan nilai dasar dari hukum, namun di antara masing-masing terdapat suatu ketegangan satu sama lain. Hubungan atau keadaan demikian itu bisa dimengerti, dikarenakan di antara ketiga nilai-nilai dasar hukum tersebut masing-masing mempunyai tuntutan yang berbeda-beda satu sana lain sehingga ketiganya mempunyai potensi untuk saling bertentangan.

Ketiga nilai dasar tujuan hukum sebagai inti ajaran Gustav Radbruch, seyogyanya menjadi dasar di dalam mengoperasikan hukum, ketiga nilai dasar tujuan hukum dalam konsep the rule of law pada negara hukum seperti Indonesia, memang dapat menimbulkan 
pertentangan dalam perwujudannya. Sebab dalam kenyataan, seringkali antara kepastian hukum berbenturan dengan kemanfaatan atau antara keadilan berbenturan dengan kemanfaatan. Bahkan, acapkali berbenturan dalam mewujudkan keadilan dan kepastian hukum (Marwan Mas, 2004: 83).

Nilai dasar hukum yang berupa keadilan, kemanfaatan dan kepastian hukum telah mendapat pengaturannya secara seimbang dalam UUK dan PKPU khususnya mengenai asas kelangsungan usaha sebagai landasan filosofis perlindungan hukum bagi debitor pailit sehubungan tidak adanya insolvency test dalam penyelesaian sengketa kepailitan yaitu sebagai berikut:

Pertama, Keadilan, yang berasal dari kata adil, menurut Kamus Bahasa Indonesia adil adalah tidak sewenang-wenang, tidak memihak dan tidak berat sebelah (Eko Hadi Wiyono, 2007: 10). Adil mengandung arti bahwa suatu keputusan dan tindakan didasarkan atas norma-norma yang berlaku sesuai aturan hukum, dengan tetap memperhatikan kepentingan masyarakat, serta keberlakuannya mempunyai kedudukan yang sama bagi semua pihak (M. Agus Santoso, 2012: 85). Aristoteles dalam bukunya "Rhetorica" menyatakan bahwa keadilan ialah memberikan kepada tiap-tiap orang apa yang berhak ia terima yang memerlukan peraturan tersendiri bagi tiap-tiap kasus. Oleh karenanya hukum harus membuat apa yang dinamakan "Algemeene Regels" (peraturan umum). Berdasarkan ketentuan ini menunjukan bahwa aturan hukum bertujuan untuk menciptakan suatu keteraturan dalam kehidupan masyarakat teratur demi kepentingan kepastian hukum, meskipun suatu waktu dapat menimbulkan ketidakadilan (Aristoteles, dalam R. Soeroso, 2007: 58). Berdasarkan hal ini menunjukan bahwa hukum harus menentukan peraturan umum, harus menyamaratakan (L.J. Van Apeldoorn, 1968: 22). Pengertian keadilan sebagaimana dijelaskan oleh Aristoteles menunjukan bahwa sesuatu dikatakan adil apabila setiap orang mendapatkan bagiannya yang oleh orang Romawi diterjemahkan dalam bahasa Latin ius suum cuique tribuere Peter (Mahmud Marzuki, 2009: 151).

Berdasarkan pendapat John Rawls menyatakan bahwa cara yang adil untuk mempersatukan berbagai kepentingan yang berbeda adalah melalui keseimbangan kepentingan itu sendiri, tanpa adanya perlakuan istimewa terhadap suatu kepentingan sehingga tercipta keadilan bagi masing-masing pihak (John Rawls, dalam Karen Leback, 2012: 53). Berdasarkan konsep pengertian keadilan yang diajarkan oleh Aristoteles dan John Rawls dalam hubungannya dengan mekanisme kepailitan, asas keadilan perlu menjadi pertimbangan dan menjadi pedoman dalam tahap pengurusan dan pemberesan harta debitor pailit (Adriani Nurdin, 2012: 318.

Kedua, Asas kelangsungan usaha sebagai perwujudan perlindungan hukum bagi debitor pailit sehubungan tidak adanya insolvency test dalam penyelesaian sengketa kepailitan tercermin dalam prinsip keadilan 
pemeriksaan perkara dan dalam tahap pengurusan dan pemberesan harta debitor pailit oleh kurator yang dalam hal ini diharapkan kurator dapat meningkatkan nilai harta pailit sehingga apabila semua utang debitor telah dibayarkan lunas dan terdapat sisa hasil penjualan harta debitor pailit tersebut dapat dipergunakan debitor untuk melanjutkan usahanya.

Kepastian hukum mengandung dua pengertian, yaitu (a) Aturan yang bersifat umum membuat individu mengetahui apa yang boleh atau tidak boleh dilakukan; (b) Keamanan hukum bagi individu dari kesewenangan pemerintah karena dengan adanya aturan yang bersifat umum itu individu dapat mengetahui apa saja yang boleh dibebankan atau dilakukan oleh negara terhadap individu. Kepastian hukum bukan hanya berupa pasalpasal dalam undang-undang, melainkan juga adanya konsistensi dalam putusan hakim antara putusan hakim satu dengan putusan hakim lainnya untuk kasus serupa yang telah diputuskan sebelumnya (Peter Mahmud Marzuki, 158). Nilai kepastian hukum dalam kaitannya dengan asas kelangsungan usaha sebagai landasan filosofis perlindungan hukum bagi debitor pailit sehubungan tidak adanya insolvency test dalam penyelesaian sengketa kepailitan tercermin dalam prinsip penyelesaian sengketa kepailitan yang secara proseduralnya telah diatur dalam UUK dan PKPU dalam menyelesaikan masalah utang piutang secara adil, cepat, terbuka dan efektif.

Ketiga, Kemanfaatan, dalam nilai kemanfaatan yang terpenting ialah kenyataan apakah hukum tersebut bermanfaat atau berguna bagi masyarakat. Nilai kemanfaatan dalam kaitannya dengan asas kelangsungan usaha sebagai landasan filosofis perlindungan hukum bagi debitor pailit sehubungan tidak adanya insolvency test dalam penyelesaian sengketa kepailitan tercermin dalam prinsip penjatuhan pailit sebagai cara yang paling akhir dalam penyelesaian utang piutang (ultimum remedium) antara debitor dan kreditor sebagai bentuk perlindungan hukum bagi debitor serta tercermin juga dalam prinsip yang dapat diketahui oleh masyarakat umum.

Kita tidak dapat menilai sahnya suatu aturan hukum dari sudut peraturannya saja, tetapi harus juga memperhatikan nilai atau kaidah hukum lainnya seperti kaidah yuridis, sosiologis dan filosofis. Kaedah hukum merupakan pedoman tentang bagaimana seyogyanya manusia bertingkah laku di dalam masyarakat. Kaedah hukum merupakan ketentuan tentang perilaku. Pada hakekatnya apa yang dinamakan kaedah adalah nilai, karena berisi apa yang seyogyanya harus dilakukan, sehingga harus dibedakan dari peraturan konkret yang dapat dilihat dalam bentuk kalimat-kalimat. Kaedah hukum dapat berubah sementara undang-undangnya (peraturan konkritnya) tetap.

\section{Asas-Asas Hukum Umum yang Mendasari Asas Kelangsungan Usaha}

Hukum yang telah memenuhi ketiga nilai dasar hukum yaitu keadilan, kemanfaatan dan kepastian hukum maka keabsahannya 
dapat diuji. Dalam situasi hukum, nilai tersebut diturunkan kembali menjadi suatu asas dengan bentuk pilihan seperti asas hukum. Apabila kata asas digabungkan dengan kata hukum, yakni menjadi asas hukum, maka maknanya adalah kebenaran yang digunakan sebagai tumpuan berfikir dan alasan berpendapat, terutama dalam penegakan dan pelaksanaan hukum (Mohammad Daud Ali, 1990: 113). Pemaknaan sederhana terhadap asas hukum tersebut memberikan gambaran kepada kita bahwa asas hukum merupakan landasan atau dasar segala sesuatu yang berkaitan dengan hukum, baik ia merupakan materi, penegakan, maupun pelaksanaanya (Abdul Rachmad Budiono, 2005: 90). Asas hukum inilah memberi makna etis kepada peraturan-peraturan hukum dari nilai-nilai etis yang dijunjung tinggi. Sehingga masyarakat mampu mengkorelasikan antara peraturan hukum dengan pandangan etis yang kemudian menjunjung suatu yang dkehendaki masyarakat tersebut (Arief Sidharta, 1999: 124). Asas hukum tidak akan habis kekuatannya karena telah melahirkan suatu peraturan hukum, melainkan akan tetap ada dan akan melahirkan peraturan-peraturan lainnya. Paton menyebut bahwa asas hukum sebagai sarana yang membuat hukum itu hidup, tumbuh dan berkembang sehingga hukum bukan sekedar sebagai kumpulan peraturan melainkan dengan mengandung nilainilai dan tuntutan-tuntutan etis (Paton dalam Satjipto Rahardjo, 2000: $45)$.

\section{Asas-Asas Khusus Hukum Kepailitan yang Mendasari Asas Kelangsungan Usaha}

Asas hukum khusus yang dimaksudkan di sini adalah asas hukum yang hanya berlaku pada bidang hukum tertentu (Lukman Santoso dan Yahyanto, 2016: 156). Jika disebut asas hukum khusus di bidang kepailitan, berarti adalah asas hukum yang berlaku secara khusus di bidang kepailitan. Menurut Sutan Remy Syahdeini, UUK dan PKPU seharusnya memuat asas-asas, baik yang dinyatakan secara tegas maupun secara tersirat termasuk Undang-Undang Kepailitan yang berlaku di Indonesia yang seyogyanya memuat asasasas yaitu sebagai berikut:

a. Asas Mendorong Investasi dan Bisnis

b. Asas "Memberikan Manfaat dan Perlindungan yang Seimbang Bagi Kreditor dan Debitor"

c. Asas "Putusan Pernyataan Pailit Tidak Dapat Dijatuhkan terhadap Debitor yang Masih Solven"

d. Asas "Persetujuan Putusan Pailit Harus Disetujui oleh Para Kreditor Mayoritas"

e. Asas "Keadaan Diam (Standstill atau Stay)"

f. Asas "Mengakui Hak Separatis Kreditor Pemegang Hak Jaminan"

g. Asas "Proses Putusan Pernyataan Pailit Tidak Berkepanjangan"

h. Asas "Proses Putusan Pernyataan Pailit Terbuka untuk Umum" 
i. Asas "Pengurus Perusahaan Debitor yang Mengakibatkan Perusahaan Pailit Harus Bertanggung Jawab Pribadi"

j. Asas "Memberikan Kesempatan Restrukturisasi Utang Sebelum Diambil Putusan Pernyataan Pailit kepada Debitor yang Masih Memiliki Usaha yang Prospektif

k. Asas "Perbuatan-perbuatan yang Merugikan Harta Pailit Adalah Tindak Pidana"

Berdasarkan kajian penulis mengenai asas kelangsungan usaha sebagai landasan filosofis perlindungan hukum bagi debitor pailit sehubungan tidak adanya insolvency test hanya tiga asas yang sesuai dengan kajian penulis yang dapat dijelaskan sebagai berikut:

1. Asas Perlindungan Yang Seimbang

a. Pasal 2 ayat 1 UUK dan PKPU mengenai hak kreditor mengajukan permohonan pailit atas debitornya dan hak debitor mengajukan permohonan pailit atas dirinya sendiri (perlindungan kepentingan kreditor dan debitor);

b. Pasal 8 ayat 1 huruf a UUK dan PKPU mengenai hak debitor untuk dipanggil dan untuk didengar keterangannya dalam hal ada permohonan pailit atas dirinya;

c. Pasal 11 ayat 3 UUK dan PKPU mengenai hak debitor dan kreditor juga kurator lain yang bukan para pihak dalam suatu kepailitan untuk mengajukan permohonan kasasi;

d. Pasal 14 ayat 1 UUK dan PKPU mengenai hak para pihak dalam suatu kepailitan untuk mengajukan peninjauan kembali ke Mahkamah Agung;

2. Asas Kelayakan untuk Dinyatakan Pailit, asas ini menghendaki bahwa permohonan pailit hanya dapat diajukan terhadap debitor yang insolven yaitu debitor yang tidak membayar utang-utangnya kepada para kreditor mayoritas. Dalam UUK dan PKPU tidak ada ketentuan yang mensyaratkan kelayakan debitor untuk dinyatakan pailit, kalau syarat untuk dinyatakan pailit sudah terpenuhi, hakim dapat saja menyatakan debitor pailit walaupun misalnya utang debitor sangat kecil dibandingkan asetnya. Jadi UUK dan PKPU tidak menganut asas kelayakan untuk dinyatakan pailit.

3. Asas ultimum remedium, asas ini menghendaki bahwa pernyataan pailit merupakan pilihan terakhir dalam menyelesaikan permasalahan utang piutang. UUK dan PKPU menganut asas ini dengan melihat bahwa sebelum pernyataan pailit diucapkan, diberikan kesempatan kepada debitor untuk mengajukan usulan perdamaian dan permohonan PKPU. Maksud daripada asas ini sejalan dengan asas pengayoman. Ketentuan mengenai perdamaian terdapat dalam Pasal 145 sampai dengan Pasal 177 UUK dan PKPU, sedangkan mengenai PKPU terdapat pada keseluruhan BAB III UUK dan PKPU. 
Peraturan perundang-undangan hukum kepailitan yang lama yaitu Faillisements Verordening S. 1905 No. 207 Jo. S. 1906 No. 348, Perpu Nomor 1 Tahun 1998 tentang Perubahan Atas Undang-Undang Kepailitan, maupun Undang-Undang Nomor 4 Tahun 1998 tentang Penetapan Pemerintah Pengganti Undang-Undang tidak mengatur secara khusus mengenai asasasas hukum kepailitan, namun pada Peraturan Perundang-undangan Hukum Kepailitan terbaru yaitu UUK dan PKPU dalam penjelasannya menyebutkan bahwa keberadaan Undang-Undang ini didasarkan kepada sejumlah asas-asas kepailitan yaitu:

\section{Asas Keseimbangan}

Undang-undang ini mengatur beberapa ketentuan yang merupakan perwujudan dari asas keseimbangan, yaitu disatu pihak terdapat ketentuan yang dapat mencegah terjadinya penyalahgunaan pranata dan lembaga kepailitan oleh debitor yang tidak jujur, dilain pihak terdapat ketentuan yang dapat mencegah terjadinya penyalahgunaan pranata dan lembaga kepailitan oleh kreditor yang beritikad tidak baik.

2. Asas Kelangsungan Usaha

Dalam undang-undang ini terdapat ketentuan yang memungkinkan perusahaan debitor yang prospektif tetap dilangsungkan.

3. Asas Keadilan

Dalam kepailitan asas keadilan mengandung pengertian bahwa ketentuan mengenai kepailitan dapat memenuhi rasa keadilan bagi para pihak yang berkepentingan. Asas keadilan ini untuk mencegah terjadinya kesewenang-wenangan pihak penagih yang tidak memperdulikan kreditor lainnya.

4. Asas Integrasi

Asas integrasi dalam kepailitan mengandung pengertian bahwa sistem hukum formal dan sistem hukum materielnya merupakan satu kesatuan yang utuh dari sistem hukum perdata dan hukum acara perdata nasional (Rahayu Hartini, :16-17).

Berdasarkan asas-asas yang dianut oleh UUK dan PKPU apabila dihubungkan dengan kajian penulis mengenai asas kelangsungan usaha sebagai landasan filosofis perlindungan hukum bagi debitor pailit sehubungan tidak adanya insolvency test, maka penulis akan membahas mengenai asas kelangsungan usaha sebagaimana dianut oleh UUK dan PKPU.

\section{Bentuk dan Mekanisme Perlindungan Hukum pada Tahap Rapat Pra Verifikasi}

Sebelum dilakukan rapat verifikasi didahului dengan adanya rapat kreditor pertama (rapat pra verifikasi) yang ditentukan oleh Hakim Pengawas dalam jangka waktu paling lambat 30 (tiga puluh) hari setelah tanggal putusan pailit diucapkan, hal ini sebagaimana dijelaskan dalam ketentuan Pasal 86 UUK dan PKPU. 
Berdasarkan ketentuan Pasal 98 UUK dan PKPU menyatakan bahwa, sejak dimulai pengangkatannya, kurator harus melaksanakan semua upaya untuk mengamankan harta pailit dan menyimpan semua surat, dokumen, uang perhiasan, efek, dan surat berharga lainnya dan memberikan tanda terima. Berdasarkan alasan untuk mengamankan harta pailit, Berdasarkan ketentuan Pasal 99 ayat 1 UUK dan PKPU menyatakan bahwa, kurator dapat meminta penyegelan harta pailit kepada pengadilan melalui Hakim Pengawas.

Berdasarkan ketentuan pasal di atas menunjukan bahwa bentuk dan mekanisme perlindungan hukum bagi debitor dalam rapat pra verifikasi ini yaitu dengan mewajibkan kurator hadir dengan tujuan sebagai berikut

1. Untuk mengetahui informasi awal mengenai aset debitor pailit;

2. Untuk mengetahui penawaran harga jual debitor terhadap asetnya dalam rangka melunasi utang-utangnya supaya harga jual aset debitor pailit mendapatkan harga jual yang optimal;

3. Untuk mendapatkan gambaran mengenai pelunasan utang-utang debitor terhadap aset yang dimilikinya;

4. Untuk mengetahui nilai utang yang debitor miliki secara terbuka oleh kreditor. Untuk mendapatkan gambaran kemungkinan pemotongan utang oleh kreditor.

Bentuk dan mekanisme perlidungan hukum lainnya terhadap debitor pada tahap rapat pra verifikasi adalah debitor ikut serta dalam rapat pra verifikasi, dimana dalam rapat ini debitor diberikan hak untuk didengarkan keterangannya dalam hal ada permohonan pailit atas dirinya.

\section{Bentuk dan Mekanisme Perlindungan Hukum pada Tahap Rapat Verifikasi}

Rapat Verifikasi berarti menguji kebenaran piutang kreditor yang dimasukkan kepada kurator, hal ini berarti bahwa verifikasi menetapkan tentang tata cara kreditor menyampaikan tagihannya agar tagihan itu dapat diakui dan ditetapkan. Rapat Verifikasi ini bermaksud untuk memeriksa dan mengesahkan tagihan-tagihan yang sudah masuk (H.M.N. Purwosutjipto, 1984: 43).

Rapat verifikasi hanya diadakan satu kali dalam kepailitan seseorang. Tagihan-tagihan yang akan dibawa ke rapat verifikasi yang sebelumnya sudah harus diselidiki oleh kurator (Ridwan Khairandy, 2014: 485). Berdasarkan ketentuan Pasal 102 UUK dan PKPU menyatakan bahwa setelah dibuatnya pencatatan harta pailit, kurator harus membuat daftar yang menyatakan sifat, jumlah piutang dan utang harta pailit, nama dan tempat tinggal kreditor beserta jumlah piutang masing-masing kreditor.

Berdasarkan ketentuan pasal ini menunjukan bahwa pada rapat ini piutang-piutang kreditor atau utang-utang debitor yang 
dinyatakan pailit yang telah didata oleh kurator untuk dicocokkan mengenai benar tidaknya pengakuan sebagai kreditor, besarnya piutang kreditor maupun kedudukannya sebagai kreditor. Bentuk dan mekanisme perlindungan hukum bagi debitor pada tahap rapat verifikasi adalah melindungi debitor pailit terhadap tagihan-tagihan yang tidak ada dasarnya.

Dalam melakukan pencocokan piutang dilakukan penetapan tentang tata cara kreditor menyampaikan tagihannya agar tagihan itu dapat diakui dan ditetapkan. Bilamana tagihan-tagihan itu (berdasarkan alat bukti yang ada) ditetapkan dengan pasti, maka tagihan-tagihan itu disebut dengan tagihan yang diakui atau tagihan yang diverifikasi, dan kreditornya disebut dengan kreditor yang diakui. Sedangkan tagihan yang tidak cocok dengan catatan si pailit, akan ditolak oleh kurator dengan disertai alasan-alasannya. Berkenaan dengan itu, maka berdasarkan ketentuan Pasal 119 UUK dan PKPU menyatakan bahwa kurator akan membuat 2 (dua) daftar tagihan, yaitu tagihan yang diterima atau diakui dan tagihan yang ditolak. Kedua daftar tagihan itu disediakan di kantor kurator selama tujuh hari sebelum diadakan rapat verifikasi, agar setiap kreditor dan setiap orang yang berkepentingan dapat melihatnya secara cumacuma.

Bentuk perlindungan hukum lainnya bagi debitor adalah debitor dapat melakukan negoisasi pembayaran utang atau pemotongan utang terhadap kreditor melalui likuidasi asetnya. Mendapatkan kepastian dari rencana likuidasi aset-aset debitor. Debitor dapat bernegoisasi untuk pemotongan utang terhadap total kemampuan likuiditas pada aset yang akan dilikuidasi.

Verifikasi utang merupakan tahap yang paling penting dalam kepailitan karena akan ditentukan urutan pertimbangan hak dari masing-masing kreditor (Adil Samadani, 2014: 74. Salah satu hal penting lainnya yang mungkin dibahas dalam rapat pencocokan utang adalah rencana perdamaian (accord), di mana debitor pailit berhak menawarkan suatu perdamaian kepada semua kreditor secara bersama hal ini sebagaimana dijelaskan dalam ketentuan Pasal 144 UUK dan PKPU.

Bentuk dan mekanisme perlindungan hukum lainnya bagi debitor berdasarkan ketentuan pasal di atas adalah perdamaian yang terjadi antara debitor dan kreditor berkaitan erat dengan kelangsungan usaha debitor yang masih memiliki prospek untuk tetap dilangsungkan, hal ini sebagaimana dijelaskan oleh Sutan Remy Syahdeini yang mengemukakan bahwa hendaknya dalam UndangUndang Kepailitan dicantumkan ketentuan bahwa sebelum sampai pada keputusan pailit dan likuidasi, baik atas permintaan kreditor maupun debitor sendiri, wajib untuk pertama-tama dan terlebih dahulu menelaah kemungkinan perusahaan debitor dapat diselamatkan dari kepailitan melalui program rehabilitasi 
perusahaan (Sutan Remy Sjahdeini, 1998: 27). Hal senada dikemukakan juga oleh Bismar Nasution, yang menyebutkan bahwa dalam reorganisasi perusahaan itu, debitor harus menyediakan informasi yang cukup agar kreditor dapat memberikan penilaian tentang rencana reorganisasi yang diupayakan oleh debitor (Bismar Nasution, 2003: 142).

\section{Bentuk dan Mekanisme Perlindungan Hukum pada Tahap Penjualan Harta Debitor Pailit}

Seorang debitor berada dalam keadaan insolven apabila dalam rapat pencocokan utang tidak ditawarkan rencana perdamaian, rencana perdamaian yang ditawarkan tidak diterima, atau pengesahan perdamaian ditolak berdasarkan putusan yang telah memperoleh kekuatan hukum tetap hal ini sebagaimana diatur dalam ketentuan Pasal 178 UUK dan PKPU.

Debitor tidak mampu secara finansial membayar sebagian besar utang-utangnya atau nilai aktiva atau asetnya kurang dari nilai pasiva atau liabilities nya. Undang-undang harus menetapkan terlebih dahulu berapa besar yang dimaksudkan dengan "sebagian besar" itu (Sutan Remy Sjahdeni, 62). Harta debitor pailit dalam keadaan insolvensi (tidak mampu membayar utang-utang debitor) apabila debitor yang telah dinyatakan pailit, pada proses pencocokan piutang tidak ditawarkan rencana perdamaian, rencana perdamaian tidak diterima, atau pengesahan perdamaian ditolak berdasarkan putusan yang mempunyai kekuatan hukum tetap ketentuan ini sebagaimana diatur dalam Pasal 178 UUK dan PKPU. Proses selanjutnya terhadap harta debitor pailit yang telah dinyatakan dalam keadaan insolvency adalah likuidasi yaitu menjual harta tersebut yang dilakukan oleh kurator. Atas hasil likuidasi itu kurator mendistribusikan kepada masing-masing kreditor dalam rangka melunasi utang debitor kepada masing-masing kreditor yang piutangnya diakui dalam proses pencocokan atau verifikasi utang piutang. Distribusi tersebut dilakukan sesuai dengan urutan masingmasing piutang mereka sebagaimana ditentukan oleh undang-undang. Tindakan kurator inilah yang dinamakan dengan "tindakan pemberesan". Di dalam praktek juga dikenal dengan istilah "likuidasi".

Akibat hukum dari adanya penetapan insolvensi terhadap debitor pailit mengakibatkan beberapa konsekuensi hukum satu di antaranya adalah harta debitor pailit dilakukan eksekusi selanjutnya dibagi sesuai dengan besar kecilnya utang terhadap kreditorkreditornya, kecuali ada pertimbangan tertentu misalnya keberlakuan asas kelangsungan usaha yang mengakibatkan terjadinya penundaan pelaksanaan eksekusi sehingga pembagian terhadap harta debitor dilakukan penundaan, yang mana nantinya masing-masing kreditor akan mendapatkan pelunasan piutang yang lebih menguntungkan dibandingkan dengan menyatakan debitor pailit. 
Pengaturan asas kelangsungan usaha dalam hukum kepailitan mempunyai peranan penting dalam memberikan perlindungan hukum bagi debitor yang memiliki kemampuan untuk melakukan restrukturisasi perusahaan sebagai upaya perwujudan asas keadilan bagi semua pihak (Adrian Sutendi, 9). Ketiadaan peraturan mengenai insolvency test dalam UUK dan PKPU dapat mengakibatkan kerugian bagi debitor. Hal ini dikarenakan untuk mempailitkan debitor tidak terdapat persyaratan dalam peraturan perundang-undangan hukum kepailitan agar debitor dalam keadaaan insolven. Tidak diterapkannya peraturan ini mengakibatkan banyak perusahaan di Indonesia dinyatakan bangkrut secara hukum. Padahal dalam kondisi krisis yang dialami oleh Indonesia saat ini apabila persyaratan insolvency itu diterapkan maka akan sulit membuat debitor Indonesia dinyatakan pailit.

Pada penerapannya banyak kasus mengenai insolvency test yang menunjukan kedudukan debitor sangat lemah, sehingga debitor yang memiliki kemampuan untuk tetap melanjutkan usahanya tidak mampu untuk bertahan, sehingga harus dinyatakan pailit. Satu di antaranya adalah kasus pailit PT AJMI yang dipailitkan oleh Pengadilan Niaga Jakarta Pusat, namun dibatalkan oleh Mahkamah Agung dalam tingkat kasasi. Selain itu kasus pailitnya TPI dan PT. Dirgantara Indonesia berdasarkan ketentuan UUK dan PKPU menunjukan bahwa test kesehatan keuangan perusahaan tidak dijadikan syarat untuk menyatakan debitor pailit. Seharusnya hakim dalam menyatakan TPI dan PT. DI pailit harus memperhatikan asas kelangsungan usaha. Pada kasus ini ketentuan Pasal 2 ayat 1 UUK dan PKPU tidak rasional, dikarenakan tidak adanya jumlah minimum utang untuk menyatakan debitor pailit. Hal ini berarti debitor yang mempunyai utang Rp.1 dapat dinyatakan pailit.

Likuidator bertanggung jawab kepada RUPS atau pengadilan yang mengangkatnya atas likuidasi perseroan terbatas yang dilakukan. Kurator bertanggung jawab kepada hakim pengawas atas likuidasi perseroan terbatas yang dilakukan. Likuidator wajib memberitahukan kepada Menteri dan mengumumkan hasil akhir proses likuidasi dalam surat kabar setelah RUPS memberikan pelunsasan dan pembebasan likuidator atau setelah pengadilan menerima pertanggung jawaban likuidator yang ditunjuknya. Ketentuan terhadap likuidator ini berlaku juga bagi kurator yang pertanggungjawabannya telah diterima oleh hakim pengawas (Binoto Nadapdap, 2014: 182).

Asas-asas dalam kepailitan yang pada umumnya ada dalam suatu negara adalah asas permohonan pernyataan pailit hanya dapat diajukan terhadap debitor yang insolvent yaitu yang tidak membayar utang-utangnya kepada kreditor mayoritas. Hal ini berarti pengadilan baru dapat menjatuhkan putusan pernyataan pailit apabila debitor dalam keadaan insolvensi. Akan tetapi pada penerapannya konsep 
insolvency test tidak diberlakukan dalam menyatakan debitor pailit. Untuk menyatakan seorang debitor pailit tidak lagi didahului dengan adanya pengujian apakah perusahaan debitor masih memiliki prospek untuk diselamatkan.

Ketentuan di atas menunjukan bahwa konsep perlindungan hukum bagi debitor sebagai upaya perwujudan asas kelangsungan usaha sehubungan dengan tidak adanya insolvency test bagi debitor belum terwujud. Tidak adanya insolvency test merupakan persoalan besar bagi debitor dikarenakan pada penerapannya debitor yang masih memiliki kemampuan untuk melakukan restrukturisasi utangutangnya harus dinyatakan pailit. Hal ini menunjukan bahwa perlindungan hukum yang diberikan oleh Undang-Undang Kepailitan lebih melindungi kepentingan kreditor. Hal ini sebagaimana dijelaskan oleh Hikmahanto Juwana yang menyatakan bahwa amandemen atas Undang-Undang Kepailitan sangat dominan melindungi kepentingan kreditor. Hal ini diperkuat dengan ketentuan yang mensyaratkan tidak perlu adanya insolvency test dalam pernyataan pailit. Kreditor menginginkan agar tagihannya dapat segera diperoleh dari debitor yang berada dalam kesulitan likuiditas sehingga Hukum Kepailitan dipergunakan sebagai alat untuk mempailitkan debitor meskipun debitor masih dalam keadaan solven (Hikmahanto Juwana, 17).

Berdasarkan uraian di atas menunjukan bahwa bentuk dan mekanisme perlindungan hukum bagi debitor pada tahap penjualan harta debitor pailit yaitu sebagai berikut:

1. Dalam melakukan penjualan harta debitor pailit, kurator hendaknya berusaha memaksimalkan nilai penjualan harta pailit, dimana dalam proses pemberesan yang merupakan penguangan aktiva untuk membayar atau melunasi utang. Pihak kurator harus memulai melakukan pemberesan dan penjualan harta kekayaan debitor pailit, tanpa harus menunggu adanya persetujuan debitor dengan tetap memperhatikan ketentuan Pasal 15 ayat 1 UUK dan PKPU sehingga apabila terdapat sisa dari hasil penjualan harta debitor, dapat dipergunakan bagi debitor untuk melanjutkan kelangsungan usahanya;

2. Debitor bisa bernegoisasi harga jual aset yang akan dilikuidasi oleh penilai atau kurator supaya harta debitor pailit dapat dijual semaksimal mungkin.

3. Dalam menyelesaikan pemberesan boedel pailit kurator harus melakukan penjualan di muka umum (lelang) sedangkan untuk penjualan di bawah tangan hanya dapat dilakukan dengan seizin Hakim Pengawas (Edward Manik, 2012: 170). Namun apabila Hakim Pengawas berpendapat terdapat cukup uang tunai maka 
Kurator diperintahkan untuk melakukan pembagian kepada kreditor yang piutangnya telah dicocokkan hal ini sebagaimana dimaksud dalam ketentuan Pasal 188 UUK dan PKPU.

\section{Perlindungan Hukum pada Tahap Pelunasan terhadap Hasil Penjualan Harta Debitor Pailit}

Kreditor yang telah dicocokkan daftar pembagiannya maka dibayarkan jumlah penuh piutang mereka, atau segera setelah daftar pembagian penutup menjadi pengikat maka berakhirlah kepailitan hal ini sebagaimana diatur dalam ketentuan Pasal 204 UUK dan PKPU. Tahap selanjutnya adalah kurator melakukan pengumuman mengenai berakhirnya kepailitan dalam Berita Negara Republik Indonesia dan surat kabar setelah itu kurator wajib memberikan pertanggungjawaban mengenai pengurusan dan pemberesan yang telah dilakukannya kepada Hakim Pengawas paling lama 30 (tiga puluh) hari setelah berakhirnya kepailitan.

Bentuk dan mekanisme perlindungan hukum bagi debitor dalam tahap pelunasan terhadap hasil penjualan harta debitor pailit adalah debitor berhak mengajukan permohonan rehabilitasi kepada pengadilan yang telah mengucapkan putusan pernyataan pailit hal ini sebagaimana diatur dalam ketentuan Pasal 215 UUK dan PKPU. Permohonan rehabilitasi yang dikabulkan oleh Pengadilan Niaga dikarenakan semua kreditor yang diakui telah memperoleh pembayaran secara memuaskan, sehingga debitor dapat kembali melanjutkan kelangsungan usaha debitor.

\section{Perlindungan Hukum Terhadap Debitor Sesudah Berakhirnya Kepailitan \\ Debitor Berhak Mengajukan Permohonan Rehabilitasi}

Setelah berakhirnya Kepailitan menurut ketentuan Pasal 166, 202, dan 207 UUK dan PKPU, maka debitor atau ahli warisnya berhak untuk mengajukan permohonan rehabilitasi kepada pengadilan yang dahulu menjatuhkan putusan pernyataan pailit tersebut hal ini sebagaimana diatur dalam ketentuan Pasal 215 UUK dan PKPU (Aco Nur, 2015: 100). Berdasarkan ketentuan pasal di atas menunjukan bahwa UUK dan PKPU mengambil sikap bahwa sekalipun kepailitan sudah berakhir, yaitu berakhir karena sebab-sebab yang ditentukan sebagai berikut:

1. Pasal 166 UUK dan PKPU yaitu karena pengesahan perdamaian telah memperoleh kekuatan hukum tetap;

2. Pasal 202 karena kreditor yang telah dicocokkan piutangnya telah memperoleh pembayaran penuh atas piutangnya tersebut;

3. Pasal 207 karena utang orang yang meninggal semasa hidupnya tidak dibayar lunas atau pada saat meninggalnya orang tersebut, harta peninggalannya tidak cukup untuk membayar utangnya. 
UUK dan PKPU dalam hal ini tidak secara otomatis membuat debitor pailit kembali berhak dapat mengelola harta kekayaannya. Untuk dapat kembali berwenang mengelola harta kekayaannya terlebih dahulu debitor pailit yang bersangkutan harus memperoleh rehabilitasi.

1) Pengertian Rehabilitasi

Berdasarkan Penjelasan Pasal 215 UUK dan PKPU mengemukakan bahwa rehabilitasi adalah pemulihan nama baik debitor yang semula dinyatakan pailit melalui putusan pengadilan yang berisi keterangan bahwa debitor telah memenuhi kewajibannya.

2) Dasar Hukum Rehabilitasi

Berdasarkan ketentuan Pasal 215 UUK dan PKPU menyatakan bahwa setelah berakhirnya kepailitan sebagaimana dimaksud dalam Pasal 166, Pasal 202, dan Pasal 207, debitor atau ahli warisnya berhak mengajukan permohonan rehabilitasi kepada pengadilan yang telah mengucapkan pernyataan pailit. UUK dan PKPU tidak secara otomatis membuat debitor pailit kembali mengelola harta kekayaannya. Untuk dapat kembali mengelola harta kekayaannya terlebih dahulu debitor pailit yang bersangkutan harus memperoleh rehabilitasi.

3) Proses Rehabilitasi

Permohonan debitor pailit maupun para ahli warisnya, berdasarkan ketentuan Pasal 216 UUK dan PKPU tidak akan diterima sebagaimana mestinya apabila surat permohonan yang dilampirkan bukti yang menyatakan bahwa semua kreditor yang diakui sudah memperoleh pembayaran tagihan yang memuaskan. Dalam Penjelasan UUK dan PKPU bahwa yang dimaksud dengan "pembayaran secara memuaskan" adalah bahwa kreditor yang diakui tidak akan mengajukan tagihan lagi terhadap debitor, sekalipun mereka mungkin tidak menerima pembayaran atas seluruh tagihannya.

Tahapan selanjutnya adalah permohonan sebagaimana dimaksud dalam Pasal 216 UUK dan PKPU tersebut harus diumukan paling sedikit dalam dua surat kabar yang ditunjuk oleh Pengadilan Niaga hal ini sebagaimana diatur dalam ketentuan Pasal 217 UUK dan PKPU. Dalam jangka waktu 60 (enam puluh) hari setelah permohonan rehabilitasi diumumkan paling sedikit dalam 2 (dua) surat kabar harian, maka setiap kreditor yang diakui dapat mengajukan keberatan terhadap permohonan tersebut, dengan memasukkan surat keberatan disertai dengan alasan di Kepaniteraan Pengadilan danPanitera harus memberikan tanda penerimaan hal ini sebagaimana diatur 
dalam Pasal 218 ayat 1 UUK dan PKPU. Keberatan sebagaimana diatur dalam Pasal 218 UUK dan PKPU hanya dapat diajukan apabila persyaratan sebagaimana dimaksud dalam Pasal 216 tidak terpenuhi hal ini sebagaimana diatur dalam ketentuan Pasal 218 ayat 2 UUK dan PKPU.

Tahapan selanjutnya adalah setelah berakhirnya jangka waktu 60 (enam puluh) hari sebagaimana dimaksud dalam Pasal 218 UUK dan PKPU, terlepas diajukan atau tidak diajukannya keberatan pengadilan harus mengabulkan atau menolak permohonan tersebut, hal ini sebagaimana diatur dalam ketentuan Pasal 219 UUK dan PKPU. Terhadap putusan pengadilan sebagaimana dimaksud dalam Pasal 219 tidak terbuka upaya hukum apapun, ketentuan ini sebagaimana diatur dalam ketentuan Pasal 220 UUK dan PKPU. Putusan yang mengabulkan rehabilitasi wajib diucapkan dalam sidang terbuka untuk umum dan harus dicatat dalam daftar umum sebagaimana diatur dalam Pasal 20 UUK dan PKPU. Ketentuan ini diatur dalam ketentuan Pasal 221 UUK dan PKPU. Dengan demikian, keputusan pengadilan niaga mengenai permohonan rehabilitasi ini merupakan putusan yang final dan mengikat dan tidak dapat diajukan upaya hukum apapun dan oleh siapapun.

4) Akibat Hukum Rehabilitasi

Berdasarkan ketentuan Pasal 215 UUK dan PKPU setelah berakhirnya kepailitan sebagaimana dimaksud dalam Pasal 166, Pasal 202 dan Pasal 207, debitor atau ahli warisnya berhak mengjukan permohonan rehabilitasi kepada pengadilan yang telah mengucapkan putusan pernyataan pailit. Dengan demikian agar debitor dapat kembali melanjutkan kegiatan usaha dan mengurus harta kekayaannya debitor harus mengajukan permohonan rehabilitasi kepada Pengadilan Niaga yang semula memeriksa kepailitan yang bersangkutan. Dengan kata lain, kewenangan untuk melanjutkan kelangsungan usahanya dan mengurus harta kekayaannya tidak terjadi demi hukum setelah tindakan pemberesan selesai dilakukan oleh kurator.

\section{Debitor Mempunyai Hak untuk Melanjutkan Usahanya}

Berdasarkan ketentuan Pasal 202 ayat 1 UUK dan PKPU menyatakan bahwa segera setelag kepada kreditor yang telah dicocokkan dibayarkan dlaam jumlah penuh piutang mereka, atau segera setelh daftar pembagian penutup mempunyai kekuatan hukum mengikat maka berakhirlah kepailitan. tindakan selanjutnya kurator setelah kepailitan berakhir karena telah berakhirnya tindakan pemberesan adalah melakukan pengumumaman 
mengenai berakhirnya kepailitan tersebut dalam Berita Negara Republik Indonesia dan surat kabar sebagaimana dimaksud dalam Pasal 15 ayat 4 UUK dan PKPU.

Berdasarkan ketentuan dalam UUK dan PKPU menyatakan bahwa sekalipun kepailitan telah berakhir, maka UUK dan PKPU tidak otomatis membuat debitor kembali berhak mengelola harta kekayaannya. Untuk dapat kembali berwenang mengelola harta kekayaannya, terlebih dahulu debitor pailit yang bersangkutan harus melakukan rehabilitasi, setelah debitor mengajukan permohonan rehabilitasi kepada Pengadilan Niaga yang semula memeriksa kepailitan debitor, maka debitor dapat kembali berwenang untuk dapat melanjutkan kegiatan usahanya dan mengurus harta kekayaannya.

\section{Kesimpulan}

Landasan filosofis pengaturan asas kelangsungan usaha dalam UUK dan PKPU sebagai perwujudan perlindungan hukum debitor pada putusan pernyataan pailit sehubungan tidak adanya insolvency test pada penyelesaian sengketa kepailitan berkaitan erat dengan pengkajian nilai dasar hukum yaitu keadilan, kepastian hukum dan kemanfaatan, asas-asas hukum umum, asas hukum kepailitan pada umumnya serta pengkajian mengenai penjelasan mengenai asas-asas khusus Hukum Kepailitan dimana dalam hal ini adalah asas kelangsungan usaha.

Bentuk dan mekanisme perlindungan hukum terhadap kelangsungan usaha debitor yang masih prospektif sesudah adanya pernyataan pailit dan sesudah berakhirnya kepailitan sehubungan tidak adanya insolvency test dalam penyelesaian sengketa kepailitan terdiri atas tahap-tahap sebagai berikut:

Perlindungan Hukum Terhadap Debitor Sesudah adanya Putusan Pernyataan Pailit bahwa bentuk dan Mekanisme Perlindungan Hukum pada Tahap Rapat Pra Verifikasi. Berdasarkan ketentuan Pasal 98 UUK dan PKPU menyatakan bahwa, sejak dimulai pengangkatannya, kurator harus melaksanakan semua upaya untuk mengamankan harta pailit dan menyimpan semua surat, dokumen, uang perhiasan, efek, dan surat berharga lainnya dan memberikan tanda terima. Berdasarkan alasan untuk mengamankan harta pailit, Berdasarkan ketentuan Pasal 99 ayat 1 UUK dan PKPU menyatakan bahwa, kurator dapat meminta penyegelan harta pailit kepada pengadilan melalui Hakim Pengawas.

Berdasarkan ketentuan pasal di atas menunjukan bahwa bentuk dan mekanisme perlindungan hukum bagi debitor dalam rapat pra verifikasi ini yaitu dengan mewajibkan kurator hadir dengan tujuan sebagai berikut: untuk mengetahui informasi awal mengenai aset debitor pailit; untuk mengetahui penawaran harga jual debitor terhadap asetnya dalam rangka melunasi utang-utangnya supaya 
harga jual aset debitor pailit mendapatkan harga jual yang optimal; untuk mendapatkan gambaran mengenai pelunasan utang-utang debitor terhadap aset yang dimilikinya; untuk mengetahui nilai utang yang debitor miliki secara terbuka oleh kreditor. Untuk mendapatkan gambaran kemungkinan pemotongan utang oleh kreditor. Bentuk dan mekanisme perlidungan hukum lainnya terhadap debitor pada tahap rapat pra verifikasi adalah debitor ikut serta dalam rapat pra verifikasi, dimana dalam rapat ini debitor diberikan hak untuk didengarkan keterangannya dalam hal ada permohonan pailit atas dirinya.

Bentuk dan Mekanisme Perlindungan Hukum pada Tahap Rapat Verifikasi. Rapat verifikasi hanya diadakan satu kali dalam kepailitan seseorang. Tagihan-tagihan yang akan dibawa ke rapat verifikasi yang sebelumnya sudah harus diselidiki oleh kurator. Berdasarkan ketentuan Pasal 102 UUK dan PKPU menyatakan bahwa setelah dibuatnya pencatatan harta pailit, kurator harus membuat daftar yang menyatakan sifat, jumlah piutang dan utang harta pailit, nama dan tempat tinggal kreditor beserta jumlah piutang masing-masing kreditor. Berdasarkan ketentuan pasal ini menunjukan bahwa pada rapat ini piutang-piutang kreditor atau utang-utang debitor yang dinyatakan pailit yang telah didata oleh kurator untuk dicocokkan mengenai benar tidaknya pengakuan sebagai kreditor, besarnya piutang kreditor maupun kedudukannya sebagai kreditor. Bentuk dan mekanisme perlindungan hukum bagi debitor pada tahap rapat verifikasi adalah melindungi debitor pailit terhadap tagihan-tagihan yang tidak ada dasarnya.

Salah satu bentuk perlindungan hukum lainnya bagi debitor yang mungkin dibahas dalam rapat pencocokan utang adalah rencana perdamaian (accord), di mana debitor pailit berhak menawarkan suatu perdamaian kepada semua kreditor secara bersama hal ini sebagaimana dijelaskan dalam ketentuan Pasal 144 UUK dan PKPU. Bentuk dan mekanisme perlindungan hukum lainnya bagi debitor berdasarkan ketentuan pasal di atas adalah perdamaian yang terjadi antara debitor dan kreditor berkaitan erat dengan kelangsungan usaha debitor yang masih memiliki prospek untuk tetap dilangsungkan.

Bentuk dan Mekanisme Perlindungan Hukum pada Tahap Penjualan Harta Debitor Pailit. Bentuk dan mekanisme perlindungan hukum bagi debitor pada tahap penjualan harta debitor pailit yaitu sebagai berikut: pertama, Dalam melakukan penjualan harta debitor pailit, kurator hendaknya berusaha memaksimalkan nilai penjualan harta pailit, dimana dalam proses pemberesan yang merupakan penguangan aktiva untuk membayar atau melunasi utang. Pihak kurator harus memulai melakukan pemberesan dan penjualan harta kekayaan debitor pailit, tanpa harus menunggu adanya persetujuan debitor dengan tetap memperhatikan ketentuan Pasal 15 ayat 1 UUK 
dan PKPU sehingga apabila terdapat sisa dari hasil penjualan harta debitor, dapat dipergunakan bagi debitor untuk melanjutkan kelangsungan usahanya; Debitor bisa bernegoisasi harga jual aset yang akan dilikuidasi oleh penilai atau kurator supaya harta debitor pailit dapat dijual semaksimal mungkin; Dalam menyelesaikan pemberesan boedel pailit kurator harus melakukan penjualan di muka umum (lelang) sedangkan untuk penjualan di bawah tangan hanya dapat dilakukan dengan seizin Hakim Pengawas. Namun apabila Hakim Pengawas berpendapat terdapat cukup uang tunai maka Kurator diperintahkan untuk melakukan pembagian kepada kreditor yang piutangnya telah dicocokkan hal ini sebagaimana dimaksud dalam ketentuan Pasal 188 UUK dan PKPU; Perlindungan hukum pada Tahap Pelunasan terhadap Hasil Penjualan Harta Debitor Pailit.

Bentuk dan mekanisme perlindungan hukum bagi debitor dalam tahap pelunasan terhadap hasil penjualan harta debitor pailit adalah debitor berhak mengajukan permohonan rehabilitasi kepada pengadilan yang telah mengucapkan putusan pernyataan pailit hal ini sebagaimana diatur dalam ketentuan Pasal 215 UUK dan PKPU. Permohonan rehabilitasi yang dikabulkan oleh Pengadilan Niaga dikarenakan semua kreditor yang diakui telah memperoleh pembayaran secara memuaskan, sehingga debitor dapat kembali melanjutkan kelangsungan usaha debitor.

\section{Saran}

Asas kelangsungan usaha dijadikan sebagai asas yang melandasi pembentukan UUK dan PKPU, walaupun asas kelangsungan usaha telah menjadi asas yang melandasi pembentukan Peraturan UUK dan PKPU, agar lebih memiliki landasan filosofis yang jelas hendaknya konsep pengertian asas kelangsungan usaha dicantumkan dalam pasal Peraturan Perundang-undangan Kepailitan di masa depan sehingga dapat memberikan kesempatan bagi debitor dan kreditor untuk mengupayakan penyelesaian utang piutang secara adil, cepat, terbuka dan efektif. Disamping itu di setiap ketentuan yang ada dalam ketentuan Undang-Undang Kepailitan harus diatur secara tegas dan jelas, sehingga interpretasi yang berbeda-beda sebagai akibat materi pengaturan Undang-Undang Kepailitan yang tidak jelas dan tegas dapat diminimalisasi. Serta perlu adanya Peraturan Pelaksana untuk menjabarkan lebih lanjut ketentuan atau pasal-pasal yang ada dalam ketentuan Undang-Undang Kepailitan khususnya mengenai asas kelangsungan usaha. Untuk memberikan perlindungan hukum terhadap kelangsungan usaha debitor yang masih prospektif sesudah adanya putusan pernyataan pailit dan sesudah berakhirnya kepailitan sehubungan tidak adanya insolvency test dalam penyelesaian sengketa kepailitan perlu dibuat mekanisme hukum acara tentang insolvency test sebagai salah satu persyaratan untuk melakukan pengujian dalam hal menyatakan debitor pailit. 
Insolvecy test juga diperlukan karena pembuktian sederhana dalam Undang-Undang Kepailitan tidak dapat menyelesaikan permohonan pernyataan pailit yang mensyaratkan utang dalam arti luas.

\section{Daftar Pustaka}

Ali, M. D. (1990). Asas-Asas Hukum Islam. Jakarta: Rajawali Pers.

Aling, D. F. (2009). Karya Ilmiah: Perlindungan Debitur dan Kreditor Dalam Undang-Undang Nomor 37 Tahun 2004 tentang Kepailitan dan PKPU Serta Dampaknya Bagi Perbankan, Manado: Departemen Pendidikan Nasional RI, Universitas Sam Ratulangi, Fakultas Hukum.

Apeldoorn, L. J. V. (1968). Pengantar Ilmu Hukum. Jakarta: Pradnja Paramita (Placeholder1).

Ardytia, W. (2004). Tesis: Perlindungan Hukum Kreditor Dalam Kepailitan: Studi Kasus Terhadap Peninjauan Kembali Reg.No.07.PK/N/2004. Semarang: Program Studi Magister Kenotaritan Program Pasca Sarjana Universitas Diponogoro.

Aristoteles, dalam R. Soeroso. (2007). Pengantar Ilmu Hukum. Jakarta: Sinar Grafika.

Ashiddiqie, J. dalam Nurul Qamar. (2014). Hak Asasi Manusia dalam Negara Hukum Demokrasi (Human Rights in Democratiche Rectsstaat). Jakarta: Sinar Grafika.

Asyhadie, Z. \& Sutrisno, B. (2012). Hukum Perusahaan dan Kepailitan. Jakarta: Erlangga.

Bagus Irawan. (2007). Aspek-Aspek Hukum Kepailitan, Perusahaan dan Asuransi. Bandung: PT. Alumni.

Budiono, A. R. (2005). Pengantar Ilmu Hukum, Malang: Bayumedia.

Harahap, Y. Tesis: Analisis Hukum mengenai Restrukturisasi Utang PT.

Terbuka Pada Proses Perdamaian Menurut Undang Kepailitan.

Sumatera Utara: Program Magister Hukum USU.

Hartini, R. (2009). Penyelesaian Sengketa Kepailitan di Indonesia:Dualisme

Kewenangan Pengadilan Niaga dan Lembaga Arbitrase. Jakarta: Kencana.

Hartono, S. (1981). Pengantar Hukum Kepailitan dan Penundaan Kewajiban Pembayaran Utang: Yogyakarta: Liberty.

Hikmah, M. (2007). Aspek Hukum Perdata Internasional dalam Perkara Kepailitan. Bandung: PT. Refika Aditama.

Hoff, J. (2000). Indonesian Bankruptcy Law. Terjemahan Kartini Muljadi: Undang-Undang Kepailitan di Indonesia, Jakarta: Tata Nusa.

Ibrahim, J. (2006). Teori dan Metode Penelitan Hukum Normatif., Malang: Bayumedia. 
Ikhwansyah, I., Judiansyah, S. D., \& Pustikasari, R. (2012). Hukum Kepailitan: Analisis Hukum Perselisihan dan Hukum Keluarga serta Harta Benda Perkawinan. Bandung:KENI.

Juwana, H. (2004). Hukum Sebagai Instrumen Politik: Intervensi Atas Kedaulatan Dalam Proses Legislasi di Indonesia. Sumatera Utara: Orasi Dies Natalis Fakultas Hukum Universitas Sumatera Utara ke-50.

Khairandy, R. (2014). Pokok-Pokok Hukum Dagang Indonesia.Yogyakarta: FH UII Press.

Manan, A. (2009). Aspek Hukum dalam Penyelenggaraan Investasi di Pasar Modal Syariah Indonesia, Jakarta: Kencana.

Manik, E. (2012). Cara Mudah Memahami Proses Kepailitan dan Penundaan Kewajiban Pembayaran Utang:Dilengkapi Dengan Studi Kasus Kepailitan. Bandung: CV. Mandar Maju.

Marzuki, P.M. (2009). Pengantar Ilmu Hukum. Jakarta: Kencana.

Marzuki, P.M. (2010a). Penelitian Hukum. Jakarta: Kencana.

Marzuki, P.M. (2010b). Penelitian Hukum Normatif. Jakarta: Kencana.

Mas, M. (2004). Pengantar Ilmu Hukum, Bogor: Ghalia Indonesia.

Muladi, dalam Rudhy A. Lontoh, Deny Kailimang, Benny Ponto(eds). (2001). Penyelesaian Utang Piutang melalui Kepailitan atau Penundaan Kewajiban Pembayaran Utang. Bandung: Alumni.

Muljadi, K. (2003). Perubahan Faillisements Verordening Dan Perpu Nomor 1 Tahun 1998 jo. UU No. 4 Tahun 1998 tentang Penetapan Perpu No. 1 Tahun 1998 tentang Perubahan atas UU tentang Kepailitan menjadi UU Jakarta: Makalah Seminar Perkembangan Hukum Bisnis di Indonesia.

Nadapdap, B. (2014). Hukum Perseroan Terbatas Berdasarkan UndangUndang No. 40 Tahun 2007, Edisi Revisi. Jakarta: Aksara.

Nasution, B. (2003). Diktat: Hukum Kepailitan. Medan: Sekolah Pascasarjana USU, Program Magister Kenotariatan.

Nating, I. (2005). Peranan dan Tanggung Jawab Kurator dalam Pengurusan dan Pemberesan Harta Pailit. Jakarta:PT Raja Grafindo Persada.

Nur, A. (2015). Hukum Kepailitan:Perbuatan Melawan Hukum oleh Debitor. Jakarta: PT. Pilar Yuris Ultima.

Nurani, N. (2009). Hukum Bisnis:Suatu Pengantar. Bandung: CV. Insan Mandiri.

Nurdin, A. (2012). Kepailitan BUMN Persero Berdasarkan atas Asas Kepastian Hukum. Bandung: PT. Alumni.

Paton, dalam Satjipto Rahardjo. (2000). Ilmu Hukum. Bandung: PT Citra Aditya Bakti.

Prodjohamidjojo, M. (2002). Proses Kepailitan Menurut Peraturan Pemerintah Pengganti Undang-Undang Nomor 1 Tahun 1998 tentang Perubahan atas Undang-Undang Kepailitan. Bandung: CV. Mandar Maju. 
Puang, V. M. H. (2011). Penerapan Asas Pembuktian Sederhana dalam Penjatuhan Putusan Pailit, Jakarta: PT. Sarana Tutorial Nurani Sejahtera (SATU NUSA).

Purwosutjipto, H.M.N. (1984). Pengertian Pokok Hukum Dagang Indonesia. Jakarta: Djambatan.

Rawls, J., dalam Karen Leback. (2012). Teori-Teori Keadilan: Analisis Kritis terhadap Pemikiran J.S.Mill, John Rawls, Robert Nozick, Reinhold Neibuhr, Jose Porfirio Miranda, Bandung:Nusa Media.

Saliman, A. R. (2014). Hukum Bisnis Untuk Perusahaan:Teori dan Contoh Kasus. Jakarta:Kencana.

Samadani, A. (2014) Dasar-Dasar Hukum Bisnis. Jakarta: Mitra Wacana Media.

Santoso, L. \& Yahyanto. (2016). Pengantar Ilmu Hukum: Sejarah, Pengertian, Konsep Hukum, Aliran Hukum dan Penafsiran Hukum. Malang: Setara Press.

Santoso, M. A. (2012). Hukum, Moral, dan Keadilan. Jakarta: Kencana.

Sastrawidjaja, M. S. (2006). Hukum Kepailitan dan Penundaan Kewajiban Pembayaran Utang. Bandung: PT. Alumni.

Sembiring, S. (2006). Hukum Kepailitan dan Peraturan PerundangUndangan yang terkait dengan Kepailitan. Bandung: Nuansa Aulia.

Setiyowati, J. E. (2003). Perlindungan Hukum Peserta Bagi Hasil di Suatu Perusahaan. Bandung: CV.Mandar Maju.

Sidharta, A. (1999). Refleksi Ilmu Hukum. Bandung: PT.Citra Aditya Bakti. Sinaga, S. M. (2012). Hukum Kepailitan Indonesia. Jakarta: Tata Nusa.

Sjahdeini, S. R. (1998). Makalah: Tanggapan terhadap Perpu Kepailitan No. 1 Tahun 1998. Jakarta.

Sudarsono. (2002). Kamus Hukum. Jakarta: Rineka Cipta.

Sunarmi. (2005). Ringkasan Disertasi: Tinjauan Kritis terhadap UndangUndang Kepailitan:Menuju Hukum Kepailitan yang Melindungi Kepentingan Debitor dan Kreditor. Medan: Pascasarjana USU, Perpu yang Bikin Kiamat, Kontan No.39 Tahun II, 29 Juni 1998.

Surya Perdamaian. (2001). Makalah: Syarat-Syarat Pengajuan Kepailitan dan Kelemahan Hukum Acara Kepailitan dalam Praktek Pengadilan Niaga. Medan.

Sutendi, A. (2009). Hukum Kepailitan, Bogor: Ghalia Indonesia.

Widijowati, R. D. (2012). Hukum Dagang. Yogyakarta: ANDI.

Wirjolukito. (1997). Penyelesaian Kepailitan melalui Pengadilan (Studi Kasus Kepailitan):Restrukurisasi Organisasi melalui Bisnis Kepailitan. Semarang: Fakultas Hukum Universitas Diponegoro.

Wiyono, E. H. (2007). Kamus Bahasa Indonesia Lengkap. Jakarta:Akar Media. 